\title{
THE FINDINGS OF THE CONTINUA- TION COMMITTEE CONFERENCES IN ASIA ON EDUCATION
}

The Report of the Continuation Committee Conferences in Asia, held in 1912-13 under the leadership of the Chairman of that Committee, Dr. John R. Mott, is a weighty and notable volume. But nothing in it is so noteworthy as the facts that made it possible. That these conferences, twenty-one in number and representing practically all denominations, nationalities and mission boards engaged in the work of Christian missions in Asia, were held, and that the leading missionaries in each of the great districts represented in these conferences could agree unanimously in the findings severally ascribed to them in this volume, is itself a fact of great significance.

Scarcely less significant perhaps is the extent of the agreement in the findings of the several conferences. Meeting in different lands, composed of course of different men, facing to some extent different problems and conditions, they returned to the similar lists of questions put to each conference answers surprisingly in agreement. Yet that there are notable differences will also shortly appear. The present paper is to pass in review the findings of the various committees on education.

1. The place of education in missionary work. This volume bears unmistakable testimony to the fact that education is now universally recognized as a legitimate and necessary missionary agency. If in any of the regions in which these conferences were held there remains any of the anti-educational sentiment $\underset{670}{6}$ which in times past has 
demanded and secured the closing of schools and the concentration of all effort on direct evangelization, the representatives of it either did not attend the conferences or being in attendance abstained from expressing their convictions by their votes. The findings of the conferences, unanimously adopted, stand unequivocally and strongly not only for evangelization but also for an aggressive educational policy. This fact gives ground to hope that it will never again be necessary to resist an anti-educational movement of any significant dimensions.

2. The aims of missionary education. On no point is there greater variety of statement in the findings of the several conferences or perhaps more real difference of opinion than on this fundamental question.

The Ceylon Conference, first mertioning evangelization, adds :

This conference . . . would press on the attention of those responsible for them [Christian schools and colieges] the encouragement it would give to the missionary cause if the training of Ceylonese missionaries were placed in the foreground of the objects for which such colleges exist.

\section{The Bombay Conference says :}

This conference desires to affirm its conviction that now, as in the past, the primary aim of all missionary educational work is the definite conversion of individuals. It recognizes, at the same time, that in the effort to carry out this aim the important work of permeating the community with Christian ideals is also being accomplished, thus fulfilling the twofold expectation expressed by the early founders of educational missions.

The statement of the Jubbulpore Conference reads almost as if it were an intentiona! criticism and emendation of that of Bombay :

Without obscuring the work of educational missions as a force for evangelization and for permeating non-Christian society with Christian ideas, great stress must be laid upon its function in building up the Christian community.

The India National Conference, adopting with some slight modification the words of the Allahak ad Conference, says : 
These mission schools have for their aims: (I) The upbuilding of the Church through the training of the children and youth of the Christian community. (2) The conversion of individual students. (3) The diffusion of Christian ideas as a preparation for the large influx of converts which we believe is coming into the Christian Church.

\section{The Shanghai Conference affirms that:}

The ultimate aim of all our educational work is the development of Christian character, thus helping to produce leaders in Church and State. [Among the agencies mentioned for achieving this end is] the holding of special services for the purpose of leading students to accept Christ and definitely to consecrate their life-work to Him.

\section{At Peking it was held that :}

The aims of Christian education are the fostering of Christian character and spiritual life in the young; the preparation of students for special service in the church as preachers, teachers, etc.; and the training of all Christians to use their vocations, whether professional, commercial, industrial or domestic, for the welfare of the people in the spirit of Christ.

\section{The China National Conference formulated its judgment thus :}

The aim of Christian education is the development of Christian character in all who come within its reach, the training of youth for lives of the highest social usefulness, and the production of Christian scholars and of Christian leaders in Church and State.

\section{The Korean group said :}

Education in Korea as carried on by Christian missions finds its field among the Christian youth of the country. Its aim is to take them at the most plastic period of life, and to make them in faith, zeal and practice, pillars and leaders in the Church of Christ, irrespective of the ultimate calling or profession they will ultimately follow.

The Japan Conferences made no pronouncement on the aims of missionary education.

It is a striking fact that while the conferences in India, Burma, and Ceylon differ among themselves as to what is the foremost aim of education, no one of them which defines the aims of education fails to include the conversion of the student, and four of the six include permeation of the non- 
Christian community with Christian ideals. The thought of the development of the Christian community as a chief function of education finds explicit expression in but one conference, the training of leaders (missionary) is emphasized in but one, and no one of them mentions benefit to the State; Burma alone includes the training of Christian leaders for the Church and society in the aims of Christian education. Thus the individualistic idea seems to be dominant in the conception of the aims of education, for permeation is apparently thought of as a preparation for conversion rather than as a benefit to the community and an end in itself.

These statements refer, let it be clearly observed, to the interest of the conferences, not in conversion or the development of the Christian community as ends in themselves, but as results to be achieved by education. The sections on Christian leadership furnish ample evidence that the Indian conferences were interested in this subject, and some of them expressly refer to the relation between the training of leaders and education. But it seems nevertheless true that that relationship received but slight emphasis in the conferences, and especially so when the subject of education was under consideration. The result is to leave the impression that, while the missionary and Christian body as a whole is sincerely and even deeply interested in the development of the Christian community and the training of native leadership, the educators are not thinking of the achievement of these ends as constituting an important part of the function of the schools.

In China, on the other hand, no conference expressly mentions either conversion or permeation among the purposes for which schools are maintained (though Shanghai and the National Conference refer to conversion indirectly), but practically all the conferences that touch upon aim refer to the training of the leaders of the Christian community, and three of them expressly mention the training of men to be leaders of the State. Korea also speaks 
definitely of the training of leaders for the Christian community.

Again it is a matter of emphasis and of relation to education. As in India there was undoubted interest in the training of Christian leaders, but relatively little recognition of its relation to education, so in China there is abundant evidence of interest in evangelization, but an apparent indisposition to avow this as one of the ends to be achieved through education.

The explanation of these differences is doubtless in large part in the local conditions. In India the proportion of non-Christian students in Christian schools is very large, sometimes amounting to over 90 per cent. In China it varies greatly, but in general is much smaller than in India. In Korea the pupils are practically all Christians. Hence the emphasis on conversion as an aim of the schools of India, and its practical absence from the findings of China and Korea. In India, again, the British Government is strong and stable, leadership in the affairs of State being almost wholly in the hands of the British, while there is an over-supply rather than a deficiency of Indians ambitious to fill positions of greater or less responsibility in the Government. But in China there is a desperate need of Chinese of ability and character to fill, with patriotism and devotion, responsible positions under the new Government. Hence the emphasis on service of the State in China, and silence on this point in India.

But if these differences in large part reflect the sensitiveness of the educational missionaries to actual needs rather than a divergence in fundamental ideals, they must perhaps be ascribed in part also to one-sidedness or inadequacy of view. One questions at any rate why the China conferences should not have found larger place for conversion among the expressly mentioned aims of education, or if exactness of statement forbid its mention among the aims of education why it might not have received fuller attention among the desirable ends for the achievement 
of which Christian schools afford opportunity. Nor is it easy on other grounds to explain some omissions which are all but universal. Thus, Jubbulpore alone finds the chief function of Christian education in the building up of the Christian community. The Indian National Conference mentions it as one among three ends, and in a few other cases the idea is perhaps latent. But the infrequency of clear expressions of it seems to indicate a limitation of vision, especially regrettable in India, a land in which the development of the Christian community calls for concentration of thought and effort.

Still more marked is the absence of any reference, save by more or less remote implication, to the welfare of the community as a whole as one of the ends to be achieved by Christian education. Several of the conferences refer to the matter indirectly, but none makes an explicit statement on this point. Perhaps this is largely due to the feeling that, with the limited resources of the schools, they cannot assume responsibility for so large a task. But to include it in the aims does not affirm that the missionary schools are alone responsible for achieving it, while the omission of it from the formulated definition of the purpose of education can scarcely fail to affect unfavourably the spirit in which the work is done. The great Christian principle that justifies and demands famine relief, hospitals and industrial schools, applies not only to these things but to all forms of activity that promote human welfare, including education, and a clear recognition of this principle in the very definition of the purpose of education could scarcely fail to make our educational work, as well as all other, more intelligent, more sympathetic and more effective. It is, of course, to be remembered that the principle is being acted upon even where it is not avowed, and is sometimes implied in the findings of the conferences where it is not expressed, as also that, since these findings are those only which were unanimously agreed to, there may have been many in every conference who would have taken the broader view. But 
it remains a significant fact that with all the remarkable unanimity on other matters no conference was unanimous in taking the broad and inclusive view of this matter.

3. The scope of Missionary educatron. On the question of the range which missionary education should cover, the findings of the several conferences are as a whole distinctly broad; and this also in a measure makes up for the limitations observable in the definitions of the purpose of education. Elementary, secondary, collegiate, theological, medical and industrial education, even in one or two cases technological education, are recognized as within the scope of missionary work. True, these are not all recognized by all the conferences, indeed several of them make no declaration on this point. But it is only by silence, not by declaration, that any of these forms of education is excluded, and in most cases an argument from silence would be unjust. If we take the matter by countries, and give special attention to the findings of the national conferences, we notice that in India the following types of education are expressly mentioned : elementary, secondary, collegiate, the training of teachers. The last named is specially insisted upon by all but one of the district conferences in India, as well as by Colombo and Singapore. The education of Indian physicians is spoken of in India by Bombay and Lahore only. Calcutta and the India National Conference commend the plan of giving some medical training to Indians who are to become evangelists. But apparently there is no recognized need of Christian medical schools of a high grade to train men to become fully educated physicians. It is surprising that only Jubbulpore and the National Conference mention theological education, especially in view of the amount of such education going on in the country.

The silence of the others cannot, of course, be understood as expressing disapproval, but is there perhaps some connexion between this silence and the already mentioned slight recognition of the connexion between education and the development of Christian leadership, and is there 
perhaps an insufficiently recognized need of theological education of a higher grade ? Industrial education is expressly mentioned by Jubbulpore and by implication by Allahabad; while Calcutta emphasizes industrial training for women. Bombay and the National Conference recognize the need of the industrial development of the Christian community, but do not expressly relate it to education.

In China the National Conference enumerates all the forms of education named above. The demand for medical education is for high-grade medical schools both for men and for women. The district conferences had anticipated the action of the National Conference in these points, all recommending in particular teacher training and medical education, all except Hankow mentioning industrial education, all except Shanghai theological education. The omission in the last case is doubtless accidental rather than intentional and significant. Two district conferences, Shantung and Hankow, even include technological education in the field of missionary education.

The strong emphasis on medical education in China as compared with India reflects a real difference in the conditions and sentiment, probably chiefly due to the fact that the British Government in India takes an active and intelligent interest in medical work, while in China the Government has as yet been able to do but little. Yet it is not wholly clear why the education of native Christian physicians has not made a stronger appeal to the missionaries in India.

Less can perhaps be made of the greater emphasis laid on theological education in China than in India. Yet even here there is doubtless a reflection of the fact that there is at present much greater activity in China than in India in the development of theological education. China's greater emphasis on industrial education is certainly surprising in view of the fact that except for the far greater efficiency of the Government, industrial conditions are much worse in India than in China. Is the explanation perhaps to be 43. 
found in the fact, reflected in their respective definitions of the purpose of education, that missionaries to India, as a class, emphasize the distinctly religious and propagandist aspect of missions, while in China there is more disposition to emphasize the expression of the Christian spirit in service to the community? And is this in turn accounted for in part by the fact that while India is in many respects worse off than China, economically and socially, yet matters are more fluid in China, change for the better seems more possible to be effected?

The Korean statement says nothing directly concerning the scope of Christian education. It seems to imply that the Christian body cannot compete with the Government in the field of industrial and technological education and must confine itself as a matter of fact, whether of choice or not, to raising up 'pillars and leaders in the Church of Christ.' Yet it guards this against narrowness by adding, 'irrespective of the calling or professions they will ultimately follow.'

The Japan Conference, though not mentioning expressly that the Christian forces have been practically excluded from work in elementary education by the strong development of government and public education in this field, yet reflects this in the fact that no mention is made of education below the middle school. The duty to serve the whole people is distinctly recognized, yet especially the obligation of the Christian school, by reason of its ability to do so, to give effective moral education, and emphasis is laid upon the necessity of raising up leaders for the Christian community. The need of higher education is strongly stated and a Christian university of the first rank is called for. It is evident that by a university is meant an institution, not such as those which the Buddhists now have or those which in America and China are misnamed universities, but one that will eventually rank with the Japanese imperial universities. That medical and industrial education are not mentioned is doubtless due to the strength of the 
national schools in these fields and to the indisposition of the Government to share the work of medical education with voluntary agencies. One is at a loss to account for the absence of any but very incidental mention of theological education, unless it is due to the fact that Japan has already far too many theological schools, and that unanimity could not be secured for anything stronger than the cautious statement, 'Missions with little or no theological equipment should earnestly consider the feasibility of co-operation, as far as possible, with schools already well equipped.'

On the whole, the statements concerning the scope of education reflect the differences in situations in the various countries, but there is in a number of cases a failure to recognize unquestionably existing opportunities which can be accounted for only by the impossibility of securing unanimity or by a reluctance to outline a programme that seemed too far beyond the possibilities of attainment. Particularly significant and encouraging is the almost universal recognition of the need of schools for training teachers. Perhaps in no other way can the mission schools so directly and effectively contribute to the building up of the Christian community or to the welfare of the nation at large as by sending out Christian teachers and educators, competently trained for work in schools of all kinds.

4. Co-operation aNd systematization. It is significant of the new period in Christian missions that with but one exception (Ceylon) every conference recommends co-operation of the various missionary bodies in the conduct of Christian schools. In several cases the recommendation mentions the special field in which the co-operation should be had. In India special emphasis is laid on the desirability of union in women's education, in the training of teachers, and in theology. In China the field of union effort specially emphasized is that of higher education, including that of women. Canton, significantly in view of the situation in South China, mentions theology in particular, but so also do Peking and Hankow. Japan desires co-operation in all 
schools above the middle school, and in particular says that ' in order to secure more efficient theological schools, such union or co-operation as is practicable should be carried out as speedily as possible.'

This strong emphasis on union in theological work marks a distinct and notable advance upon conditions ten years ago, when such co-operation except between the bodies of the same name from different regions was scarcely thought of as possible, and even in such cases was not always effected. As late as 1909, even in West China, where there has been so high a measure of harmony and co-operation, it was thought that union could not be extended to include theological work.

There is a general demand for an educational union, or a central committee on Christian education in the several districts and countries, almost every conference recommending this. Almost universal also is the recommendation for an organized (union) system of Christian education, sometimes with specific mention of the need of a superintendent of education. Korea says that by means of the Educational Federation they are well on the way to a single system for the whole country-a statement that could not have been made five years ago. In the Mukden Conference it was recommended, and might well have been in all the China conferences, that the Christian system of education should be as closely assimilated as possible to that of the Government, and that the matter of government inspection of Christian schools and of having government representatives on the boards of management of Christian colleges should be carefully considered. Shanghai recommends equal representation of Chinese and foreigners on the boards controlling educational work, and the China National Conference recommends the largest practicable Chinese representation. Christian Chinese are evidently in mind. While in Japan nothing is said on this point under the head of education, the section on the Japanese Church adopted by the missionaries and that adopted by the joint conference 
of missionaries and Japanese both declare that the administration of all affairs must gradually be transferred to the Japanese.

In all this one finds little to criticize, and can only hope that these ideals may be cherished both by missionary educators and by boards at home, and that they may as rapidly as possible come to realization.

5. Women's education. That women's education is separately treated in a number of the conferences reflects both the fact that the importance of the subject is recognized as it was not formerly and that it has not yet fully come into its own. In India the Madras Conference calls for a Union Women's College in South India, the Bombay Conference asks for such a college for West India, the Calcutta Conference emphasizes the need of training Christian girls for home duties and building them up in Christian character but does not ask for a college. The India National Conference urges co-operation in particular for the purpose of establishing one women's college in each province in which a demand for such a college exists. Most of the China conferences emphasize the importance of the education of women, some demanding opportunities equal to those of men; Shanghai and Tsi-nan-fu specifically call for a women's college. The China National Conference takes the former position. That Peking does not mention a women's college is perhaps due to the fact that it already has one. Had there been a West China Conference, as unfortunately there was not, it would certainly have pronounced for a college for women. In Japan the missionaries and the Japanese leaders unite in calling for a first-class women's college. That Singapore and Korea do not do the same is not evidence of less interest in women's education, but of a recognition that differing conditions call for different institutions.

In conclusion, it is to be said that the reports as a whole are most encouraging. They show a keen perception of the educational needs of the great countries of the Orient, 
and of the boundless opportunities of service that are thus set before the Christian communities of the West, and a sane and sober outlook on the whole situation. If they sometimes seem to disclose a less comprehensive view and vision of the possibilities of work of this kind than could be desired, this is accounted for in part by the fact that only unanimous conclusions are here published, and by the difficulty of securing perfect unanimity of opinion; in part also perhaps by the unreasonable demand of the critic for ideal statements rather than practical proposals. The dominant impressions that one brings away from the study of the findings of the several conferences are : first, the great educational value of the conferences themselves; secondly, the remarkable and on the whole admirable comprehensiveness and clearness of view of those who participated in them; and thirdly, the greatness and the difficulty, yet also the inspiring character of the task which is set before the Christian Church of this day. If only the Church could catch this vision, and rise to the opportunity! Almost the only serious criticism that one feels constrained to offer is on the partial failure clearly to recognize the full breadth of the task of Christian education. Ernest D. Burton 